Hjørdis Hjukse

Universitetet i Sørøst-Norge

Toril Aagaard

Universitetet i Sørøst-Norge

Agnete Andersen Bueie

Universitetet i Sørøst-Norge

Thomas Moser

Universitetet i Sørøst-Norge

Karl Solbu Vika

Universitetet i Sørøst-Norge

DOI: http://dx.doi.org/10.5617/adno.8023

\title{
Digitalisering i grunnskolelærerutdanningen: Om faglige forskjeller i arbeidet med profesjonsfaglig digital kompetanse
}

\begin{abstract}
Sammendrag
Forskning viser at utviklingen av lærerstudenters profesjonsfaglige digitale kompetanse (PfDK) i svak grad har vært arbeidet med i norsk grunnskolelærerutdanning. Imidlertid er det behov for oppdaterte studier og kunnskap om hvordan ulike fag i dag arbeider med PfDK. I artikkelen har vi lagt Rammeverk for lererens profesjonsfaglige digitale kompetanse (lansert av Utdanningsdirektoratet i 2017) til grunn når vi har innhentet og analysert data. Vi undersøker om det er forskjell mellom hvordan lærerutdannere fra ulike faggrupper legger til rette for studenters PfDK-utvikling og hva som karakteriserer arbeidet med implementering av PfDK i fagene. Studien har et deskriptivt design basert på selvrapporterte data fra en tverrsnittsundersøkelse om PfDK, gjennomført ved fem norske lærerutdanningsinstitusjoner. Vi finner at det er tydelig sammenheng mellom faggruppetilhørighet og hvordan lærerutdannere arbeider med PfDK, men lærerutdannernes «vurdering av egen teknologibruk» er også av betydning for hvordan de implementerer PfDK. Lærerutdannere i Pedagogikk og elevkunnskap og i den sammensatte kategorien «annet» oppgir i større grad enn de andre å jobbe med PfDK. Lærerutdannere fra samfunnsfag skårer over gjennomsnittet, de fra språkfag og praktiskestetiske fag skårer omtrent på gjennomsnittet, mens lærerutdannere fra KRLE og realfag skårer under. En del profesjonsaktuelle PfDK-temaer vies generelt lite oppmerksomhet i alle fag. Resultatene gir innsikt som er relevant for nasjonale rammesettere og grunnskolelærerutdanninger i deres arbeid med å sikre at alle lærerstudenter utvikler PfDK og blir godt forberedt for å utøve yrket i en digital tid.
\end{abstract}

Nøkkelord: profesjonsfaglig digital kompetanse, PfDK, grunnskolelærerutdanning, profesjonsfaglige tverrfaglige temaer, PfDK-rammeverk 


\title{
Digitalization in teacher education: How professional digital competence is addressed in different subjects
}

\begin{abstract}
Research shows that the development of teacher students' professional digital competence (PDC) has been given little priority in Norwegian teacher education (for primary and lower secondary level). However, we need updated studies about how PDC is addressed in different subjects in TE. In this article, we use PDC in line with how it is presented in Professional Digital Competence: A Framework for Teachers, launched by the Directorate for Education and Training in 2017. We investigate differences between how teacher educators from various subject groups facilitate teacher students' development of PDC, and what characterizes the implementation of PDC in these groups. The study has a descriptive cross-sectional design based on self-reported data from five Norwegian teacher education institutions. Results reveal a clear association between subject group affiliation and how teacher educators work with PDC. In addition, we find that how teacher educators evaluate their own technology use, also affects how they implement PDC. Teacher educators in Pedagogy and in the mixed subject group named Other address PDC to the greatest extent. Teacher educators in Social Sciences score above average. Teacher educators in Language and in PracticalAesthetic subjects score approximately on average, while teacher educators working with KRLE (Christianity, Religion, Philosophies of life and Ethics) and with the STEM subjects score below. Some PDC topics that have received attention in the teacher profession, are paid little attention to across all subject groups. Our results provide new insights relevant to national stakeholders and teacher educations in their effort to ensure that all teacher students develop PDC and become well prepared for their future worklife in a digital age.
\end{abstract}

Keywords: professional digital competence, PDC, teacher education, professional interdisciplinary topics, PDC framework

\section{Introduksjon}

I denne artikkelen undersøker vi hvordan ulike fag i grunnskolelærerutdanningen (GLU) i Norge arbeider med å utvikle studentenes profesjonsfaglige digitale kompetanse (PfDK). I 2017 lanserte Utdanningsdirektoratet (Senter for IKT i utdanning) Rammeverk for lcererens profesjonsfaglige digitale kompetanse (Kelentrić, Helland \& Arstorp, 2017) som gir innhold til begrepet PfDK. Dette norske rammeverket gir retning for kompetanseutvikling i skoler og for lærerutdanningsinstitusjoner som arbeider med å sikre at lærerstudenter blir godt forberedt for yrket de skal ut i (Kelentrić et al., 2017). Det presenterer kompleksiteten i hva som kreves av lærerens profesjonsutøvelse i et digitalt samfunn. Kompetanser kategoriseres i sju områder: Fag og grunnleggende ferdigheter; Skolen i samfunnet; Etikk; Pedagogikk og fagdidaktikk; Ledelse av læringsprosesser; Samhandling og kommunikasjon; og Endring og utvikling. Områdene 
er hentet fra Meld. St. 11 (2008-2009) om lærerprofesjonen (KD, 2009), hvilket kan forklare rammeverkets fokus på profesjonsutøvelse.

Arbeidet med å tilpasse skole og utdanning til utfordringer og muligheter som digitalisering medfører, har pågått i flere år. Kunnskapsdepartementet (KD) introduserte digitale ferdigheter som en av fem grunnleggende ferdigheter i 2006. Andelen elever som har sin egen pc eller nettbrett øker (Fjørtoft, Thun \& Buvik, 2019), og mange klasserom har 1:1-dekning. Lærere i 1:1-klasserom erfarer at det er blitt enklere å tilpasse opplæringen til den enkelte elev (Tømte, Wollscheid, Bugge \& Vennerød-Diesen, 2019; Wølner, Egeberg, Moser, Bjørnsrud \& Aagaard, 2019). På tvers av utdanningsnivå ser vi at digital teknologi inviterer til arbeid i læringsfellesskap (Kongsgården, 2018) og åpner for mer elev- og studentaktiv læring og demokratisk deltakelse (Aagaard \& Lund, 2020). Digitalisering utløser også utfordringer, som omfattende utenomfaglig aktivitet i undervisningen (Blikstad-Balas, 2013; Wølner et al., 2019) og digital mobbing (Macaulay, Betts, Stiller \& Kellezi, 2018).

Noen av mulighetene og utfordringene ved digitalisering har blitt tydelige under Covid-19 i 2020. Sosial digital teknologi gjorde det mulig å opprettholde undervisningen selv om skoler og universitet stengte. I sosiale medier gav mange lærere uttrykk for at hjemmeskolen gjorde det enklere å se den enkelte eleven og tilpasse opplæringen. For enkelte elever så hjemmeskolen ut til å gi gode læringsvilkår, mens andre opplevde løsere rammer og uvante arbeidsformer som krevende. Situasjonen har vist at lærerutdanningen ikke bare må forberede lærerstudenter for ordinære situasjoner og for hvor fort vilkår for læring kan endres. Covid-19 krevde at lærere tok i bruk digital teknologi på nye måter, og at de trengte endrings- og utviklingskompetanse for å omstille seg raskt.

Det er for tidlig (mai 2020) å dokumentere hvordan Covid-19 kommer til å påvirke arbeidet med PfDK i lærerutdanningen. Tidligere har imidlertid forskere nasjonalt og internasjonalt påpekt at lærerutdanninger i begrenset grad har lyktes med å utvikle studentenes PfDK (Gudmundsdottir, Loftsgarden \& Ottestad, 2014; Krumsvik, 2016; Tømte, Kårstein \& Olsen, 2013), og at sektoren trenger kunnskap om hva lærerutdannere bruker digital teknologi til og hvilken kompetanse de trenger (Nelson, Voithofer \& Cheng, 2019). Dette lå til grunn da KD i 2017 lyste ut 90 millioner kroner til digitalisering av GLU. Midlene ble fordelt på fem grunnskolelærerutdanningsinstitusjoner som i perioden 2018-2020 har jobbet særskilt med å utvikle PfDK i GLU (Utdanningsdirektoratet, 2018). Vår studie belyser hvordan lærerutdannere fra ulike fag ved disse institusjonene i 2019 rapporterte at de jobbet med PfDK.

$\mathrm{Vi}$ analyserer resultatene fra en survey som ble laget med utgangspunkt i rammeverket for PfDK, og som ble utviklet av forfatterne i samarbeid med de øvrige institusjonene og Nordisk institutt for studier av innovasjon, forskning og utdanning (NIFU). NIFU gjennomførte den første analysen av dataene (Daus, Aamodt \& Tømte, 2019) og fant at den digitale utviklingen er viktig for lærerutdannere, at holdningen til digitalisering er mer positiv enn skeptisk, at 
lærerutdannere vurderer seg selv som middels gode til å tilrettelegge studenters PfDK-utvikling, og at digitalisering endrer lærerrollen og arbeidsmåter i faget. Respondentene var i mindre grad enige om at fagenes innhold endres. Vektleggingen av PfDK er sterkest ved Universitetet i Sørøst-Norge (USN). Daus et al. (2019) peker på at GLU har et betydelig utviklingsbehov når det gjelder å implementere PfDK i utdanningen.

I denne artikkelen analyserer vi dataene fra den samme surveyen, men nå for å få svar på følgende forskningsspørsmål:

- Hvilken betydning har fagtilknytning for lcererutdannernes arbeid med PfDK? - Hva karakteriserer arbeidet med implementering av PfDK i fagene?

Studien gir innsikt i hvordan fagene forbereder lærerstudentene på å utøve yrket i en digital tid. Institusjonene forventes å ivareta studentenes PfDK-utvikling i et studieprogram som er sammensatt av en rekke fag, men med få fellesfag. I 2017 ble GLU femårig masterutdanning. Hensikten var å styrke kvaliteten gjennom økt differensiering og fagspesialisering. I utdanningen for 1. til 7. trinn (GLU 1-7) ble norsk, matematikk, og pedagogikk og elevkunnskap (PEL) fellesfag. For 5. til 10. trinn (GLU 5-10) ble PEL eneste fellesfag. Studiemodellene gir dermed få felles møteplasser for studentene. Svar på våre forskningsspørsmål er en forutsetning for å vurdere og diskutere om fagenes bidrag til studentenes PfDKutvikling er tilstrekkelig.

\section{Hva er PfDK?}

Kompetanse som begrep ble brukt allerede av Platon (Mulder, Gulikers, Biemans \& Wesselink, 2009), men har fått ny oppmerksomhet, blant annet i diskusjoner om hva digitalisering krever av endring i utdanning (Furberg \& Lund, 2016; Lund, Furberg, Bakken \& Engelien, 2015). Kompetanse kommer til uttrykk når mennesker klarer å kombinere kunnskap, ferdigheter og holdninger til å løse spesifikke oppgaver eller komplekse problemer på måter som fungerer godt (Mulder et al., 2009). PfDK er den kompetansen en lærer trenger for å undervise elever og studenter på gode måter i en digital kontekst. Vi bruker begrepet PfDK slik det beskrives i Utdanningsdirektoratets rammeverk (Kelentrić et al., 2017). PfDK-rammeverket er policyutviklet, men bygger på innspill fra forskningsmiljøer og hvordan lignende kompetanser er forsøkt beskrevet av internasjonale aktører (Kelentrić et al., 2017). Vi anvender rammeverket, både fordi det er profesjonsspesifikt og fordi lærerutdanningsinstitusjonene som er inkludert i surveyen bruker det i sin institusjonsutvikling.

Historisk er det gjort mange forsøk på å beskrive denne kompetansen, som også er gitt mange navn. I en mye brukt modell, Technological Pedagogical Content Knowledge (TPACK), synliggjør Koehler og Mishra (2009) at 
teknologisk, pedagogisk og fagkunnskap må kombineres når digitale undervisningspraksiser skal utvikles. Modellen inviterer lærere til å reflektere over og begrunne undervisningsvalg, men studier viser blant annet at de tre kunnskapskategoriene er krevende å sortere i (Voogt, Fisser, Pareja Roblin, Tondeur \& Van Braak, 2013), og modellen gir ingen føringer for i hvilken retning det er fornuftig å utvikle undervisning. DigCompEdu (Redecker, 2017) gir tydeligere retning, blant annet ved å peke på noen pedagogiske verdier, som «empowering learners», differensiering, personalisering og å gi studenter rollen som aktør i egen utdanning. DigCompEdu retter seg mot lærere på alle nivåer (grunnskole til høyere utdanning) og er derfor svært generell.

Til forskjell fra de internasjonale rammeverkene presentert over, operasjonaliserer det norske rammeverket kompetansen en lærer i grunn- og videregående skole trenger for å undervise i en digital tid. Rammeverket er derfor spesielt relevant for GLU, som forbereder lærerstudenter for lærerprofesjonen.

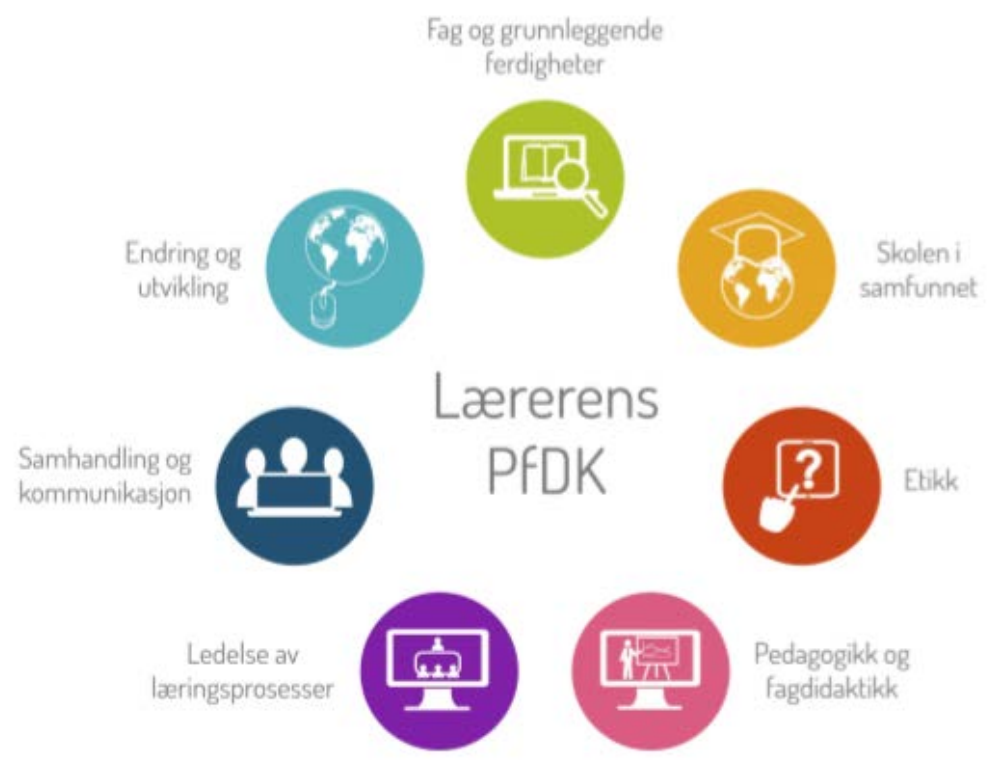

Figur 1. Hovedområdene i PfDK-rammeverket

Som vist i figur 1, angir rammeverket sju hovedområder en lærer - som profesjonell yrkesutøver i en digital kontekst - må ha kompetanse i. Under hvert av områdene i figuren listes mål som beskriver hva en lærer må kunne. En av kompetansene er, som i de andre nevnte rammeverkene, å kunne vurdere hvordan digital teknologi kan brukes i planlegging, gjennomføring og evaluering av undervisning i fag. Men mer omfattende og profesjonsspesifikke kompetanser etterspørres i det norske rammeverket. For eksempel må en lærer med PfDK forstå hvordan digital utvikling endrer fagenes innhold; ha kunnskap om digitale mediers betydning for elevers oppvekst; vite hvordan digitale skiller kan motvirkes; kunne bidra til å forberede elever for et arbeidsliv i endring; kjenne lover, for eksempel om opphavsrett; kunne identifisere og involvere elever i arbeid med digitalt utløste etiske problemstillinger; kunne bruke digital teknologi 
til å fremme et inkluderende læringsmiljø, samarbeid og kunnskapsdeling; bruke digital teknologi til å tilpasse opplæringen; og så videre.

Fag er trukket inn i alle de nevnte rammeverkene, men felles for dem er at det overlates til institusjoner og lærere å løse hvordan PfDK kan komme til uttrykk i fagdidaktiske grep, i faglige oppgaver og innhold.

\section{Hva vet vi om PfDK i lærerutdanningen?}

Som vist, indikerer flere studier at utvikling av PfDK-områder ikke blir tilstrekkelig høyt prioritert i norsk lærerutdanning (Gudmundsdottir \& Hatlevik, 2018; Gudmundsdottir et al., 2014; Krumsvik, 2016; Tømte et al., 2013). Det samme fremgår av studier om IKT i lærerutdanningen (LU) i andre land (Arstorp, 2015; Foulger, Graziano, Schmidt-Crawford \& Slykhuis, 2017; Nelson et al., 2019; Tondeur, van Braak, Siddiq \& Scherer, 2016).

Tømte et al. (2013) konkluderer med at digital kompetanse i liten grad blir beskrevet i emneplaner, og at digitaliseringsarbeidet er svakt forankret i ledelsen. Dermed blir tilnærmingen til studentens PfDK-opplæring fragmentert og i stor grad overlatt til ildsjeler. Forfatterne anbefaler sterkere forankring i fag og emneplaner, kompetanseløft hos samtlige ansatte slik at de kan være gode rollemodeller, og å trekke de beste praksisskolene inn i undervisningen i LU.

I nyere tid er det gjort tiltak på nasjonalt plan for å styrke og institusjonalisere PfDK-satsingen. Rammeverket er et slikt tiltak. Med etableringen av ProTed, Senter for fremragende lærerutdanning, ble større lærerutdanningsmiljøer gjort til pådrivere for utvikling av utdanningskvalitet og operasjonalisering av PfDK. Rindal, Lund og Jakhelln (2015) indikerer at ProTed lyktes i å institusjonalisere arbeidet med å utvikle LU ved Universitetet i Oslo (UiO) og Universitetet i Tromsø (UiT). I samarbeid med praksisfeltet har fagmiljøet utviklet kunnskap som styrker forutsetningene for å lykkes med å implementere PfDK i utdanningen. Det ble for eksempel avdekket at mangel på felles forståelse medfører at digital kompetanse oppfattes og behandles forskjellig i ulike fag og utdanninger (Rønningsbakk, Jakhelln \& Vedeler, 2015, s. 134). Ved UiT ble dette løst ved å designe den såkalte Tromsøtrappa (Rindal et al., 2015, s. 20) hvor digital kompetanseutvikling skjer på tvers av fag gjennom studiet. Tilstrekkelig med tid, tilgang til relevant teknologi og gode rammer for samarbeid har vist seg å være avgjørende faktorer for å lykkes med dette (Rønningsbakk et al., 2015). I forbindelse med innføring av 5-årig lærerutdanning i 2017 etablerte flere utdanningsinstitusjoner modeller som var inspirert av Tromsøtrappa, fordi man vurderte at dette var en god løsning for å fremme tverrfaglige kompetanseområder som PfDK (Rindal et al., 2015, s. 20).

Forskningsbasert kunnskap om digitalisering i LU, særlig basert på kvantitative data, er svært begrenset (Uerz, Volman \& Kral, 2018). I en kunnskapsoversikt analyserer Uerz et al. (2018) 26 artikler om lærerutdanning og digitalisering. De 
påpeker at det å integrere teknologi i LU krever følgende: For det første må lærerutdannere kunne bruke digital teknologi til å forbedre sin egen undervisning og for å stimulere til at studentene når sine læringsmål. For det andre må de kunne modellere god didaktisk praksis og derigjennom lære studentene å bruke teknologi på hensiktsmessige måter i skolen. For det tredje må de lære studentene hvordan de kan legge til rette for utvikling av elevens digitale kompetanse. Dette ligger til grunn for begrepet "second-order teachers» som innebærer at lærerutdannere både må forberede studentene på yrkesutøvelse i teknologirike klasserom, men også tematisere den modellerte undervisningen og de pedagogiske begrunnelsene som ligger bak. For øvrig krever digitalisering innovasjonskompetanse og evne og vilje til profesjonell utvikling. Uerz et al. (2018) anbefaler kompetansetiltak som er nært knyttet til lærerutdannernes undervisningskontekst, som inkluderer tverr- eller flerfaglig samarbeid, er skreddersydd til LUs behov og som stimulerer til reflekterende læring.

Ingen av de nevnte studiene undersøker hvordan lærere i ulike fag forholder seg til digitalisering og PfDK-utvikling. Søk i relevante databaser bekrefter at det er begrenset forskning på feltet. Imidlertid har Voithofer, Nelson, Han og Caines (2019) undersøkt hvilke faktorer som påvirker hvordan rammeverket TPACK (Koehler \& Mishra, 2009) integreres i amerikanske lærerutdanninger, med respondenter fra fagene engelsk, matematikk, naturfag og «educational technology». Selv om fagforskjeller ikke er et hovedanliggende i denne studien, viser den små forskjeller mellom hvordan respondenter i de ulike fagene rapporterer at de integrerer TPACK (engelsk 34 \%, matematikk $37 \%$, naturfag $35 \%$ ). Faglærere i «educational technology» implementerer i større grad TPACK (46 \%).

Røkenes og Krumsvik (2016) viser at faglærere i LU er viktige forbilder når studenter skal lære å bruke digital teknologi i undervisning. Lærerstudentene trenger selv læringserfaringer med å integrere IKT i fagene, ikke bare å lære om bruk på et overordnet, generelt nivå. Aagaard (2015) viser at didaktiske fagtradisjoner kan være ulike, og at elevers tilgang til digital teknologi forstyrrer i enkelte fag mer enn i andre. Lærerne i Mediefag gir elever i stor grad arbeidslivsrelevante oppgaver der digital teknologi trengs for å kunne svare, og de opptrer selv som veiledere. Norsklærere forteller imidlertid om timer med formidling av norskfaglig innhold og PCer som utløser forstyrrende utenomfaglig aktivitet blant elevene (Aagaard, 2015). Aase (2009) påpeker at den kunnskapsteoretiske basisen i ulike skolefag varierer og at den er basert på ulike kulturelle tradisjoner. Ifølge Aagaard (2015) prøver enkelte norsklærere å forebygge utenomfaglig aktivitet og tilpasse undervisningen ved å utvikle en didaktikk som ligner medielærernes. De norsklærerne hun beskriver, viser hvordan digital teknologi kan tas i bruk innenfor norskfagets rammer, og hvordan den bidrar til å endre fagdidaktiske tradisjoner. Derfor er det behov for å utvikle fagspesifikke strategier for hvordan elever tilegner seg kunnskap i en digital tid. Spørsmålet, slik vi ser det, er hvordan dette kan gjøres i GLU. 


\section{Design og metode}

I denne studien undersøker vi hvilken betydning fagtilknytning har for lærerutdannernes arbeid med PfDK og hva som karakteriserer de ulike fagenes arbeid med PfDK. For å svare på dette brukes et deskriptivt design basert på selvrapporterte data fra en tverrsnittsundersøkelse gjennomført ved hjelp av et elektronisk spørreskjema.

\section{Instrument for datainnsamling}

Spørreskjemaet ble utviklet i samarbeid mellom 17 ansatte fra de fem deltakende lærerutdanningsinstitusjonene og NIFU. Fra lærerutdanningsmiljøene deltok prosjektlederne fra de fem PfDK-prosjektene og personer med spesifikk PfDKkompetanse. Surveyen ble pilotert og revidert før gjennomføring og er tilgjengelig som vedlegg 2 i NIFU-rapporten (Daus et al., 2019). Den ble gjennomført i SurveyXact (https://www.surveyxact.com/).

Skjemaet består av 74 spørsmål/utsagn hvorav 73 har lukkede svaralternativer, oftest med en skala 1-4. Sju av spørsmålene innhenter bakgrunnsopplysninger om informantene (kjønn, alder, stilling, institusjonstilknytning og undervisningserfaring). Spørreskjemaets første del omhandler lærerutdannernes perspektiver og vurderinger på digitalisering generelt, mens andre del omhandler de sju kompetanseområdene i PfDK-rammeverket.

Undersøkelsen har ikke til hensikt å kartlegge implementering av PfDKrammeverket i GLU nasjonalt, men hvordan lærerutdannere fra de fem institusjonene som fikk prosjektmidler, forholder seg til områdene i rammeverket. Utsagnene i batteriet er laget med utgangspunkt i rammeverkets sju områder og de tilhørende målene. I utvikling av batteriet erfarte man at spørsmål knyttet til kompetanseområdene Pedagogikk og fagdidaktikk og Ledelse av læringsprosesser ble svært sammenfallende, og områdene ble slått sammen. Med tanke på å oppnå så høy svarprosent som mulig, ble antall utsagn i spørreskjemaet redusert i løpet av utviklingsprosessen, og undersøkelsen speiler derfor en forenklet versjon av rammeverket.

Da surveyen ble utviklet, fantes det ingen validerte instrumenter for å undersøke arbeidet med PfDK i LU med utgangspunkt i PfDK-rammeverket. Fordi surveyen aldri hadde vært gjennomført tidligere, gjorde NIFU en konfirmerende faktoranalyse (Daus et al., 2019). De undersøkte hvorvidt de PfDKbaserte dimensjonene i spørreskjemaet reflekterte funnene i det empiriske materialet, og konkluderte med at utsagnene i stor grad representerte kompetanseområdene, med unntak av området Endring og utvikling. Kun to påstander var knyttet til dette området: hvorvidt det legges til rette for at studentene får kjennskap til relevant forskning om bruk av digitale læremidler i undervisning, og til innholdet i nasjonale styringsdokumenter knyttet til læring og undervisning i digitale omgivelser. Vi vurderer at to påstander er for få, i statistisk forstand, til å danne en selvstendig faktor eller avdekke manglende sammenheng mellom 
utsagnene. Påstandene var derfor ikke egnet til å måle området Endring og utvikling tilfredsstillende, og vi er tilbakeholdende med å tolke og diskutere funnene fra dette PfDK-området.

Vårt utvalg er noe ulikt NIFUs. Derfor gjennomførte vi en ny konfirmerende faktoranalyse, og resultatene var noe mer varierte. Enkelte av de statistiske parameterne, som måler hvor godt den teoretiske PfDK-modellen passer til dataene, viste god modelltilpasning, mens andre ikke gjorde det. Vi anså det likevel som forsvarlig å bruke NIFUs faktorstruktur, og dermed holde oss tett til modellen for det nasjonale PfDK-rammeverket.

\section{Undersøkelsesgruppe}

Populasjonen for studien er ansatte i undervisnings- og forskningsstillinger ( $\mathrm{n}=630$ ) fra Norges teknisk-naturvitenskapelige universitet (NTNU), Høgskolen i Volda (HVO), Høgskolen i Østfold (HiØ), Universitetet i Agder (UiA) og Universitetet i Sørøst-Norge (USN). Disse institusjonene fikk midler til digitalisering av GLU fra KD.

Av 630 potensielle respondenter fullførte 291 (46 \%) hele undersøkelsen, og utvalget er generert gjennom selvseleksjon. Selv om vi ikke kan kontrollere det, er det sannsynlig at det finnes systematiske forskjeller mellom de som har valgt å delta og de som ikke deltok. Vi kan for eksempel anta at de med størst interesse for PfDK er overrepresentert, og det kan tenkes at institusjonene med høy deltakelse har arbeidet mer med PfDK enn de andre. Men også andre institusjonelle særtrekk kan forklare at svarprosenten mellom de fem institusjonene varierer og kan påvirke resultatene.

Tabell 1. Antall ansatte som mottok spørreskjemaet og svarprosenter ved hver av institusjonene

\begin{tabular}{lcccc}
\hline Institusjon & $\mathrm{N}$ & $\begin{array}{c}\AA \text { Apnet ikke } \\
\text { unders } \varnothing \text { kelsen } \\
(\%)\end{array}$ & $\begin{array}{c}\text { Gjennomførte } \\
\text { spørreskjemaet } \\
(\%)\end{array}$ & $\begin{array}{c}\text { Besvarte mer enn } \\
\text { halvparten av } \\
\text { spørsmålene (\%) }\end{array}$ \\
\hline Hi $\varnothing$ & 76 & 43 & 54 & 54 \\
HVO & 53 & 32 & 58 & 60 \\
NTNU & 166 & 59 & 30 & 33 \\
UiA & 140 & 49 & 43 & 44 \\
USN & 195 & 37 & 56 & 58 \\
Alle & 630 & 46 & 46 & 48 \\
\hline
\end{tabular}

Det ble nødvendig å omgruppere respondentene i nye faggrupper av to grunner. For det første var det behov for å skape grupper av tilstrekkelig størrelse til å gjennomføre statistiske analyser. For det andre hadde respondentene mulighet til å krysse av for mer enn ett fag, inkludert kategoriene praksis og «annet». Dermed var det ikke mulig å tilordne hver respondent til ett fag. Det forelå heller ingen informasjon som kunne brukes til å vekte andelen av respondentenes undervisning i ulike fag, eller arbeidsressurser brukt på praksis eller «annet». For å unngå overlapping, slo vi sammen beslektede fag til faggrupper. Fagene pedagogikk og spesialpedagogikk ble slått sammen til pedagogikk og elevkunnskap (PEL). Norsk, engelsk og andre språkfag ble slått sammen til gruppen språk. Matematikk 
og naturfag er slått sammen til realfag. Vi undersøkte også om det var mulighet for å slå samfunnsfag sammen med kristendom, religion, livssyn og etikk (KRLE), men det viste seg at svarene mellom disse fagene ofte divergerte. Siden det kun var tre respondenter som underviste i begge fag, ble samfunnsfag og KRLE opprettholdt som selvstendige fag, og de tre respondentene ble ekskludert. Musikk, kunst og håndverk, kroppsøving, og mat og helse utgjør faggruppen praktisk-estetiske fag (PEF). I tillegg fantes kategoriene praksis og «annet». De fleste som krysset av for disse alternativene, hadde også krysset av for ett fag. Etter å ha sortert disse i faggrupper, stod vi igjen med 22 respondenter som tilhørte flere fag, og 3 som kun hadde oppgitt praksis. Disse 25 ble ekskludert fra analysene.

Lærerutdannere som falt under kategorien «annet», skåret systematisk høyere enn andre. Etter tilordningen av respondenter fra kategorien «annet» til faggrupper, kontrollerte vi at signifikante forskjeller mellom faggruppene ikke skyldtes en skjevfordeling av disse. Dette ble gjort ved hjelp av en variansanalyse med PfDK som avhengig variabel, og de seks faggruppene samt en dummyvariabel for «annet» som uavhengige variabler. Siden det fremdeles var signifikante forskjeller mellom faggruppene, kunne vi gå ut ifra at gruppeforskjellene ikke kun skyldes at respondentene fra gruppen «annet» var plassert i faggrupper.

Seks av de elleve respondentene fra gruppen «annet», som ikke oppgav annen faggruppetilhørighet, skrev i et åpent kommentarfelt at de jobber med IKT i læring/PfDK/digital kompetanse, som vi vet at en del av institusjonene tilbyr som valgfag eller videreutdanning. De øvrige fem oppgav veiledningspedagogikk, matematikkdidaktikk, drama, mens en er ansatt i en Praksis 2-stilling.

Tabell 2. Respondenter fordelt på faggrupper

\begin{tabular}{lrr}
\hline Faggrupper & Antall & Prosent \\
\hline Pedagogikk og elevkunnskap & 52 & 16.6 \\
Språkfag & 74 & 23.6 \\
Realfag & 83 & 26.4 \\
Samfunnsfag & 32 & 10.2 \\
Kristendom, religion, Livssyn, Etikk & 12 & 3.8 \\
Praktisk-estetiske fag & 50 & 15.9 \\
Annet & 11 & 3.5 \\
Totalt & 314 & 100.0 \\
\hline Totalt (314) inkluderer de som har svart på hele undersøkelsen, eller mer enn $50 \%$ av spørsmålene, \\
og som har svart på fagtilhørighet.
\end{tabular}

\section{Dataanalyse}

De statistiske analysene ble gjennomført med Stata versjon SE 15.1. For å undersøke forskjellene i arbeid med PfDK mellom faggruppene ble det anvendt variansanalytiske metoder for å sammenligne gjennomsnittsverdiene til faggruppene. Grupperingen av utsagn i de ulike PfDK-områdene er lik den NIFU har benyttet i sine analyser (Daus et al., 2019). De avhengige variablene, som representerer PfDK-områdene, ble konstruert ved å summere svarverdiene til alle 
utsagn (variabler) som inngår i et område og dele summen på antall utsagn. Slik fikk vi verdier for hver enkelt respondents skår for hvert av de seks PfDKområdene. Verdiene varierer fra 1 til 4, hvor 4 uttrykker fullstendig enighet med alle utsagnene som konstituerer det respektive kompetanseområdet. For å sikre at forskjellene mellom faggruppenes PfDK-skårer ikke skyldes andre forhold, ble det gjennomført en sammenligning mellom gruppene for de følgende bakgrunnsvariablene:

(1) alder (med kategoriene "<41 år», «41-50 år» og «>50 år»)

(2) undervisningserfaring i lcererutdanningen (med kategoriene « $<5$ år», «515 år» og «>15 år»)

(3) undervisningserfaring fra skoleverket (i år) fra grunnskole og videregående skole

(4) institusjonstilknytning (fem lærerutdannings-institusjoner)

(5) vurdering av nivå på egen teknologibruk i undervisningen (med kategoriene «nybegynner», «moderat bruker», «erfaren bruker» og «ekspert»)

(6) erfaring med å utvikle digitale ressurser (med kategoriene «ja» og «nei»)

(7) holdninger til hvordan digitalisering virker inn på kunnskapsarbeid og fagets innhold, arbeidsmåter og lcererrollen (med kategoriene «uenig», «verken-eller» og «enig»)

Multivariate analyser ble brukt for å undersøke sammenhengen mellom PfDKområdene, faggruppetilhørighet og bakgrunnsvariabler. For å sikre at forutsetningene for variansanalysene var oppfylt, benyttet vi Levenes test for å undersøke varianshomogenitet og Shapiro-Wilk-testen i tillegg til visuell kontroll av normaliteten i fordelingen, og boxplots for å identifisere ekstremverdier (se Field, 2013, s. 429-477). I kovariansanalysen (ANCOVA) med kontinuerlige variabler sjekket vi om det var noen interaksjon mellom kovariatet og den avhengige variabelen for å undersøke hvorvidt forutsetningen om homogene regresjonskurver var oppfylt. Variansanalyser (ANOVA) ble brukt for å sjekke om det var uavhengighet mellom kovariatet og den uavhengige variabelen (se Field, 2013, s. 478-506). I de tilfellene hvor forutsetningene for en ANCOVA ikke var oppfylt, ble det konstruert en kategorisk variabel for å kontrollere resultatene. I alle tilfeller var resultatene fra disse to analysene i overenstemmelse med hverandre og slik validerte de resultatene fra ANCOVA-analysen.

For å svare på det andre forskningsspørsmålet, om hva som karakteriserer arbeidet med PfDK i fag og forskjellene mellom fagene, analyserte vi enkeltpåstander fra PfDK-områdene ved hjelp av Kruskal-Wallis' H-test. Enkeltpåstandene var ikke kontinuerlige, og denne ikke-parametriske testen ble brukt fordi den avhengige variabelen er målt på ordinalnivå. 


\section{Resultater}

Når det gjelder det første forskningsspørsmålet, hvilken betydning fagtilknytning har for lcererutdannernes arbeid med PfDK, gir tabell 3 et overordnet svar. Den presenterer en oversikt over hele undersøkelsesgruppens og de enkelte faggruppenes skårer på hvert av de seks PfDK-områdene. Videre viser tabell 3 resultatene fra signifikanstesting av forskjellene mellom faggruppene (variansanalysen: feilsannsynlighet og andel forklart varians). Den forklarte variansen $\left(\mathrm{R}^{2}\right)$ indikerer at fagtilhørighet betyr mest innenfor PfDK-området Skolen i samfunnet $\left(\mathrm{R}^{2}=0.3403\right.$, dvs. $\left.34 \%\right)$ og minst på innenfor området Fag og grunnleggende ferdigheter $\left(\mathrm{R}^{2}=0.0883\right.$, dvs. $\left.8.8 \%\right)$.

Tabell 3. Totalgruppens og faggruppenes skårer i de inkluderte seks PfDK-områdene (middelverdi, standardavvik) og analyse av forskjellene mellom faggruppene (ANOVA)

\begin{tabular}{|c|c|c|c|c|c|c|}
\hline Faggrupper & $\begin{array}{l}\text { Fag og } \\
\text { grunnleggende } \\
\text { ferdigheter }\end{array}$ & $\begin{array}{l}\text { Skolen i } \\
\text { samfunnet }\end{array}$ & Etikk & $\begin{array}{l}\text { Pedagogikk, } \\
\text { fagdidaktikk } \\
\text { og ledelse av } \\
\text { læringsprosesser }\end{array}$ & $\begin{array}{l}\text { Samhandling } \\
\text { og } \\
\text { kommunikasjon }\end{array}$ & $\begin{array}{l}\text { Endring og } \\
\text { utvikling }\end{array}$ \\
\hline Total & $2.96(.61)$ & $2.73(.75)$ & $2.93(.68)$ & $2.54(.66)$ & $2.91(.62)$ & $2.73(.78)$ \\
\hline PEL & $3.09(.55)$ & $3.26(.54)$ & $3.29(.50)$ & $2.65(.68)$ & $3.29(.48)$ & $3.02(.66)$ \\
\hline SPRÅK & $2.93(.64)$ & $2.79(.65)$ & $2.94(.68)$ & $2.50(.60)$ & $2.97(.49)$ & $2.79(.73)$ \\
\hline REAL & $2.80(.69)$ & $2.14(.64)$ & $2.57(.69)$ & $2.40(.66)$ & $2.60(.66)$ & $2.62(.78)$ \\
\hline SAMF & $3.03(.52)$ & $3.17(.61)$ & $3.17(.56)$ & $2.57(.50)$ & $2.94(.68)$ & $2.70(.71)$ \\
\hline KRLE & $2.67(.30)$ & $2.24(.67)$ & $2.77(.44)$ & $2.30(.74)$ & $2.57(.59)$ & $2.08(.76)$ \\
\hline PEF & $2.99(.49)$ & $2.72(.62)$ & $2.92(.72)$ & $2.52(.60)$ & $2.84(.54)$ & $2.54(.81)$ \\
\hline ANNET & $3.77(.15)$ & $3.58(.35)$ & $3.36(.56)$ & $3.67(.30)$ & $3.63(.38)$ & $3.63(.44)$ \\
\hline $\mathrm{p}$ & $\begin{array}{l}F:<0.001 \\
W:<0.001\end{array}$ & $<0.001$ & $<0.001$ & $<0.001$ & $<0.001$ & $<0.001$ \\
\hline $\mathrm{R}^{2}$ & 0.0883 & 0.3403 & 0.1438 & 0.1233 & 0.1867 & 0.1107 \\
\hline $\mathrm{N}$ & 269 & 273 & 272 & 266 & 269 & 267 \\
\hline
\end{tabular}

TOTAL= samlet resultat for alle faggruppene; PEL= Pedagogikk og elevkunnskap; SPRÅK=Språkfag; REAL=Realfag; SAMF=Samfunnsfag; KRLE=Kristendom, religion, livssyn og etikk; PEF=Praktisk-estetiske fag; ANNET=Andre fag; $p=$ feilsannsynligheten knyttet til F-testen; w: feilsannsynligheten knyttet til Welch's ANOVA; $R^{2}=$ forklart varians; $\mathrm{N}=$ Antall respondenter.

Tabell 4 viser hvilke faggrupper som skårer signifikant forskjellig fra hverandre innenfor hvert av de seks kompetanseområdene. Analysen avdekker signifikante forskjeller mellom faggrupper på alle kompetanseområdene, hvor særlig faggruppene PEL og «annet» skiller seg fra de andre gruppene. De fleste forskjeller mellom faggruppene er på områdene Skolen i samfunnet og Samhandling og kommunikasjon. 
Tabell 4. Oversikt over signifikante forskjeller $(\mathrm{p}<0.05)$ mellom faggruppene i PfDK-områdene (post hoc test: Bonferroni og Games Howell)

\begin{tabular}{|c|c|c|c|c|c|c|}
\hline & $\begin{array}{l}\text { Fag og } \\
\text { grunnleggende } \\
\text { ferdigheter } *\end{array}$ & $\begin{array}{l}\text { Skolen i } \\
\text { samfunnet }\end{array}$ & Etikk & $\begin{array}{l}\text { Pedagogikk, } \\
\text { fagdidaktikk og } \\
\text { ledelse av } \\
\text { læringsprosesser }\end{array}$ & $\begin{array}{l}\text { Samhandling og } \\
\text { kommunikasjon }\end{array}$ & $\begin{array}{l}\text { Endring og } \\
\text { utvikling }\end{array}$ \\
\hline PEL & & $\begin{array}{l}>\text { SPRÅK } \\
>\text { REAL } \\
>\text { KRLE } \\
>\text { PEF }\end{array}$ & $>$ REAL & $<$ ANNET & $\begin{array}{l}>\text { REAL } \\
>\text { KRLE } \\
>\text { PEF }\end{array}$ & $>$ KRLE \\
\hline SPRÅK & $<$ ANNET & $\begin{array}{l}>\text { REAL } \\
<\text { PEL } \\
<\text { ANNET }\end{array}$ & $>$ REAL & $<$ ANNET & $\begin{array}{l}>\text { REAL } \\
<\text { ANNET }\end{array}$ & $>$ KRLE \\
\hline REAL & $<$ ANNET & $\begin{array}{l}<\text { PEL } \\
<\text { SAMF } \\
<\text { PEF } \\
<\text { ANNET }\end{array}$ & $\begin{array}{l}<\text { SPRÅK } \\
<\text { SAMF } \\
<\text { ANNET } \\
<\text { PEL }\end{array}$ & $<$ ANNET & $\begin{array}{l}<\text { PEL } \\
<\text { SPRÅK } \\
<\text { ANNET }\end{array}$ & $<$ ANNET \\
\hline SAMF & $<$ ANNET & $\begin{array}{l}>\text { KRLE } \\
>\text { REAL }\end{array}$ & $>$ REAL & $<$ ANNET & & $<$ ANNET \\
\hline KRLE & $<$ ANNET & $\begin{array}{l}<\text { PEL } \\
<\text { ANNET } \\
<\text { SAMF }\end{array}$ & & $<$ ANNET & $\begin{array}{l}<\text { PEL } \\
<\text { ANNET }\end{array}$ & $\begin{array}{l}<\text { PEL } \\
<\text { SPRÅK } \\
<\text { ANNET }\end{array}$ \\
\hline PEF & $<$ ANNET & $\begin{array}{l}>\text { REAL } \\
<\text { PEL } \\
<\text { ANNET }\end{array}$ & & $<$ ANNET & $\begin{array}{l}<\text { PEL } \\
<\text { ANNET }\end{array}$ & $<$ ANNET \\
\hline ANNET & $\begin{array}{l}>\text { SPRÅK } \\
>\text { REAL } \\
>\text { SAMF } \\
>\text { KRLE } \\
>\text { PEF }\end{array}$ & $\begin{array}{l}>\text { KRLE } \\
>\text { PEF } \\
>\text { SPRÅK } \\
>\text { REAL }\end{array}$ & $>\mathrm{REAL}$ & $\begin{array}{l}>\text { PEL } \\
>\text { SPRÅK } \\
>\text { REAL } \\
>\text { SAMF } \\
>\text { KRLE } \\
>\text { PEF }\end{array}$ & $\begin{array}{l}>\text { SPRÅK } \\
>\text { REAL } \\
>\text { KRLE } \\
>\text { PEF }\end{array}$ & $\begin{array}{l}>\text { REAL } \\
>\text { SAMF } \\
>\text { KRLE } \\
>\text { PEF }\end{array}$ \\
\hline \multicolumn{7}{|c|}{$\begin{array}{l}\text { *På kompetanseområdet Fag og grunnleggende ferdigheter ble det i tillegg til Bonferroni-testen også anvendt Games } \\
\text { Howell-testen (fordi forutsetningen om homogen varians ikke er oppfylt), noe som medførte at også forskjellen mellom } \\
\text { PEL og Annet ble signifikant. PEL= Pedagogikk og elevkunnskap; SPRÅK=Språkfag; REAL=Realfag; SAMF=Samfunnsfag; } \\
\text { KRLE=Kristendom, religion, livssyn og etikk; PEF=Praktisk-estetiske fag; ANNET=Andre fag. }\end{array}$} \\
\hline
\end{tabular}

Vi har kontrollert for mulige effekter av de nevnte sju bakgrunnsvariablene (alder; lærerutdanningserfaring; undervisningserfaring fra skolen; institusjonstilknytning; vurdering av nivå på egen teknologibruk; erfaring med å utvikle digitale ressurser; holdning til digitalisering) ved å kombinere disse med de to konstante variablene faggruppe og arbeid med PfDK-områdene. Alder og lærerutdanningserfaring viste ingen signifikante assosiasjoner med PfDK-områdene. I tabell 5 vises forskjellene mellom faggruppene som forblir signifikante $(\mathrm{p}<0.05)$ når det kontrolleres for de resterende fem bakgrunnsvariablene. De fleste av forskjellene mellom faggruppene forblir signifikante, og det kommer frem at faggruppen forklarer mest av de identifiserte forskjellene. 
Tabell 5. Signifikante forskjeller $(\mathrm{p}<0.05)$ mellom faggrupper i PfDK-områdene (post hoc test: Bonferroni) etter å ha kontrollert for bakgrunnsvariabler

\begin{tabular}{|c|c|c|c|c|c|c|}
\hline & $\begin{array}{l}\text { Fag og } \\
\text { grunnleggende } \\
\text { ferdigheter }\end{array}$ & $\begin{array}{l}\text { Skolen i } \\
\text { samfunnet }\end{array}$ & Etikk & $\begin{array}{l}\text { Pedagogikk, } \\
\text { fagdidaktikk } \\
\text { og ledelse av } \\
\text { læringsprosesser }\end{array}$ & $\begin{array}{l}\text { Samhandling og } \\
\text { kommunikasjon }\end{array}$ & $\begin{array}{l}\text { Endring og } \\
\text { utvikling }\end{array}$ \\
\hline PEL & & $\begin{array}{l}>\text { SPRÅK } \\
>\text { REAL } \\
>\text { KRLE }\end{array}$ & $>$ REAL & $<$ ANNET & $\begin{array}{l}>\text { REAL } \\
>\text { KRLE } \\
>\text { PEF }\end{array}$ & $>$ KRLE \\
\hline SPRÅK & $<$ ANNET & $\begin{array}{l}>\text { REAL } \\
<\text { PEL } \\
<\text { ANNET }\end{array}$ & & $<$ ANNET & & \\
\hline REAL & $<$ ANNET & $\begin{array}{l}<\text { PEL } \\
<\text { SPRÅK } \\
<\text { SAMF } \\
<\text { PEF } \\
<\text { ANNET }\end{array}$ & $\begin{array}{l}<\text { PEL } \\
<\text { SAMF }\end{array}$ & $<$ ANNET & $\begin{array}{l}<\text { PEL } \\
<\text { ANNET }\end{array}$ & \\
\hline SAMF & & $\begin{array}{l}>\text { REAL } \\
>\text { KRLE }\end{array}$ & $>$ REAL & $<$ ANNET & & \\
\hline KRLE & & $\begin{array}{l}<\text { PEL } \\
<\text { SAMF } \\
<\text { ANNET }\end{array}$ & & $<$ ANNET & $\begin{array}{l}<\text { PEL } \\
<\text { ANNET }\end{array}$ & $\begin{array}{l}<\text { PEL } \\
<\text { ANNET }\end{array}$ \\
\hline PEF & & $\begin{array}{l}>\text { REAL } \\
<\text { ANNET }\end{array}$ & & $<$ ANNET & $<$ PEL & < ANNET \\
\hline Annet & $\begin{array}{l}\text { > SPRÅK } \\
\text { > REAL }\end{array}$ & $\begin{array}{l}>\text { SPRÅK } \\
>\text { REAL } \\
>\text { KRLE } \\
>\text { PEF }\end{array}$ & & $\begin{array}{l}>\text { PEL } \\
>\text { SPRÅK } \\
>\text { REAL } \\
>\text { SAMF } \\
>\text { KRLE } \\
>\text { PEF }\end{array}$ & $\begin{array}{l}>\text { REAL } \\
>\text { KRLE }\end{array}$ & $\begin{array}{l}>\text { KRLE } \\
>\text { PEF }\end{array}$ \\
\hline
\end{tabular}

Sammenlignet med kontrollvariablene har fagforskjellene gjennomgående den høyeste partielle effektstørrelse $\left(\eta^{2}\right)$ for alle PfDK-områdene med unntak av variabelen Vurdering av nivå på egen teknologibruk (se tabell 6). Faggruppetilhørighet har størst påvirkning for områdene Skolen i samfunnet og Etikk, mens vurdering av nivå på egen teknologibruk har større forklaringskraft enn faggruppetilhørighet på tre områder: Fag og grunnleggende ferdigheter, Pedagogikk, fagdidaktikk og ledelse av læringsprosesser, og Endring og utvikling. Faggruppetilhørighet og vurdering av egen teknologibruk har tilnærmet lik påvirkningskraft på området Samhandling og kommunikasjon. Dette betyr at en lavere skår på noen PfDK-områder kan ha sammenheng med at respondenten opplever nivået på sin egen teknologibruk i undervisningen som lavt. Tabell 6 viser at vurderingen av egen teknologibruk i undervisningen forklarer $13.3 \%$, mens faggruppetilhørighet forklarer kun 7.2 \% av variasjon på PFDK-området Fag og grunnleggende ferdigheter. For området Endring og utvikling bidrar disse to variablene med henholdsvis $12.8 \%$ og $8.9 \%$, og for området Pedagogikk, fagdidaktikk og ledelse av 
læringsprosesser henholdsvis $17.8 \%$ og $10.1 \%$. Omvendt forklarer faggruppetilhørighet 36.5 \% av variasjonen på området Skolen i samfunnet mot vurdering av egen teknologibruk 8.1 \%, og 15.5 \% mot 8.7 \% på området Etikk. Variablene forklarer omtrent like mye når det gjelder variasjonen i PfDK-området Samhandling og kommunikasjon.

Tabell 6. Toveis variansanalyse, PfDK-områder, faggruppe og vurdering av nivå på egen teknologibruk PfDK-områder

\begin{tabular}{|c|c|c|c|c|c|c|c|}
\hline \multicolumn{2}{|c|}{$\begin{array}{l}\text { Uavhengige } \\
\text { variabler }\end{array}$} & \multirow{2}{*}{$\begin{array}{l}\text { Fag og } \\
\text { grunn- } \\
\text { leggende } \\
\text { ferdigheter } \\
.072\end{array}$} & \multirow{2}{*}{$\begin{array}{l}\text { Skolen i } \\
\text { samfunnet } \\
.365\end{array}$} & \multirow{2}{*}{$\begin{array}{l}\text { Etikk } \\
\\
.155\end{array}$} & \multirow{2}{*}{$\begin{array}{l}\text { Pedagogikk, } \\
\text { fagdidaktikk } \\
\text { og ledelse av } \\
\text { læringsprosesser } \\
.101\end{array}$} & \multirow{2}{*}{$\begin{array}{l}\text { Samhandling og } \\
\text { kommunikasjon } \\
.219\end{array}$} & \multirow{2}{*}{$\begin{array}{l}\text { Endring } \\
\text { og } \\
\text { utvikling }\end{array}$} \\
\hline \multirow[b]{2}{*}{$\eta^{2}$} & Faggrupper & & & & & & \\
\hline & $\begin{array}{l}\text { Vurdering } \\
\text { av egen } \\
\text { teknologibruk }\end{array}$ & .133 & .081 & .087 & .178 & .229 & .128 \\
\hline
\end{tabular}

Til det første forskningsspørsmålet viser altså resultatene at det er en tydelig assosiasjon mellom faggruppetilhørighet og hvordan lærerutdannere arbeider med PfDK, men også at vurdering av nivå på egen teknologibruk er av betydning for dette arbeidet. Studiens andre forskningsspørsmål retter seg mot forskjeller i arbeidet med implementering av PfDK mellom faggruppene. Vi vil svare på dette ved å se nærmere på påstander fra fem av de inkluderte seks PfDK-områdene. Som nevnt er vi tilbakeholdende i tolkningen av funnene på området Endring og utvikling, og har derfor ikke inkludert utsagn fra dette området i denne analysen.

De enkelte påstandene har blitt valgt enten fordi de viste stor variasjon mellom faggruppenes svar, eller fordi lærerutdannere fra noen faggrupper kun i liten grad eller ikke i det hele tatt adresserer disse påstandene. Svarene på utsagnene gir etter vår vurdering et relevant innblikk i hva som karakteriserer de ulike fagenes arbeid med PfDK og skaper dermed et grunnlag for å diskutere konsekvensene dette har for GLU.

\section{Fag og grunnleggende ferdigheter}

Figur 2 viser hvordan lærerutdannere fra ulike fag responderer på påstanden: Jeg legger til rette for at lærerstudenter lærer hvordan ulike digitale ressurser kan brukes for å differensiere innhold tilpasset den enkelte elev. Figuren viser at $67 \%$ av KRLE-lærerne og 53 \% av realfagslærerne kun i liten grad eller ikke i det hele tatt legger til rette for at studentene lærer hvordan digitale ressurser kan brukes for å differensiere innhold tilpasset den enkelte elev. Selv om $20 \%$ av respondentene fra PEL oppgir at de i liten grad legger til rette for dette, er PEL det faget som i størst grad er opptatt av det, og forskjellene er signifikante når det gjelder realfag $(\mathrm{p}<0.001)$ og KRLE $(\mathrm{p}<0.05)$. 


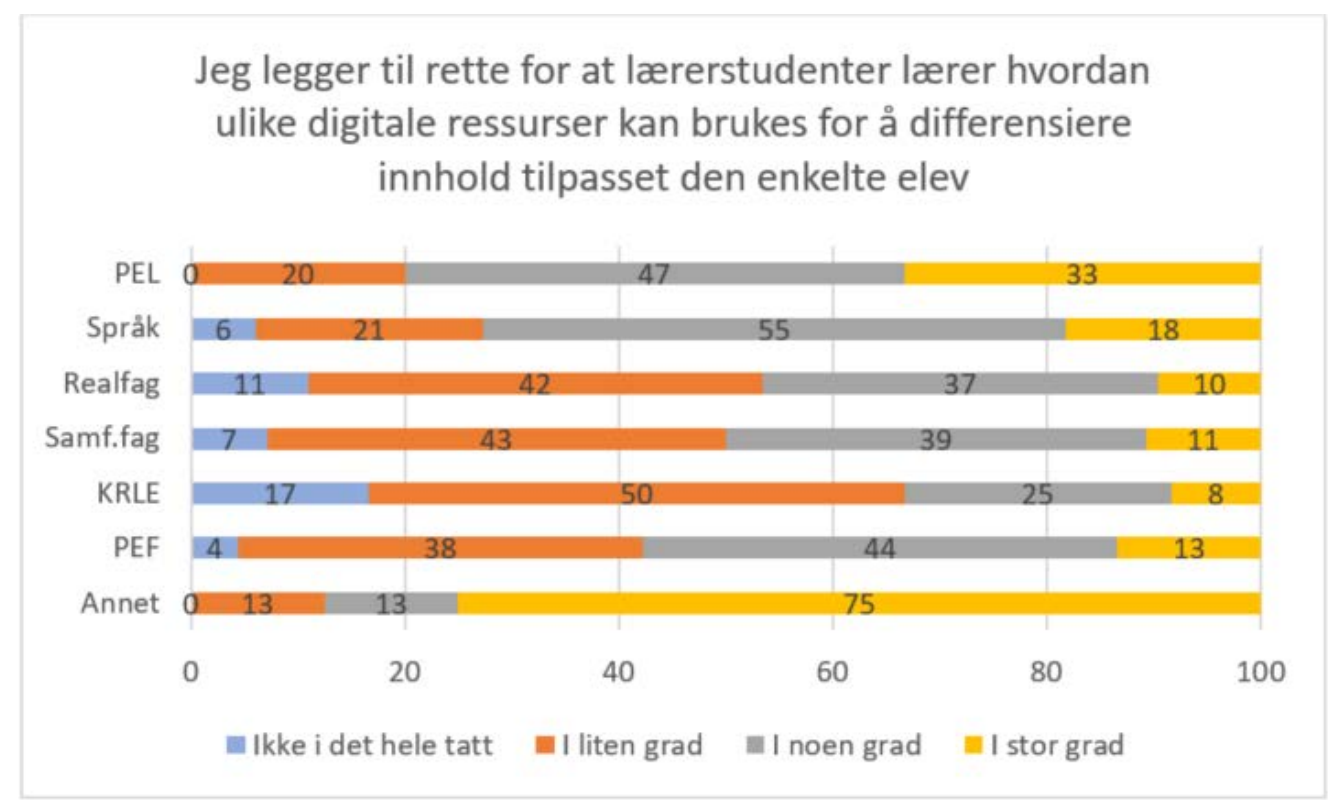

Figur 2. Digital teknologi, differensiering og tilpasset opplæring

\section{Skolen i samfunnet}

Figur 3 viser responsen på påstanden: Jeg legger til rette for at lærerstudenter får et faglig reflektert forhold til hvordan digital utvikling påvirker barn og unges oppvekstmiljø.

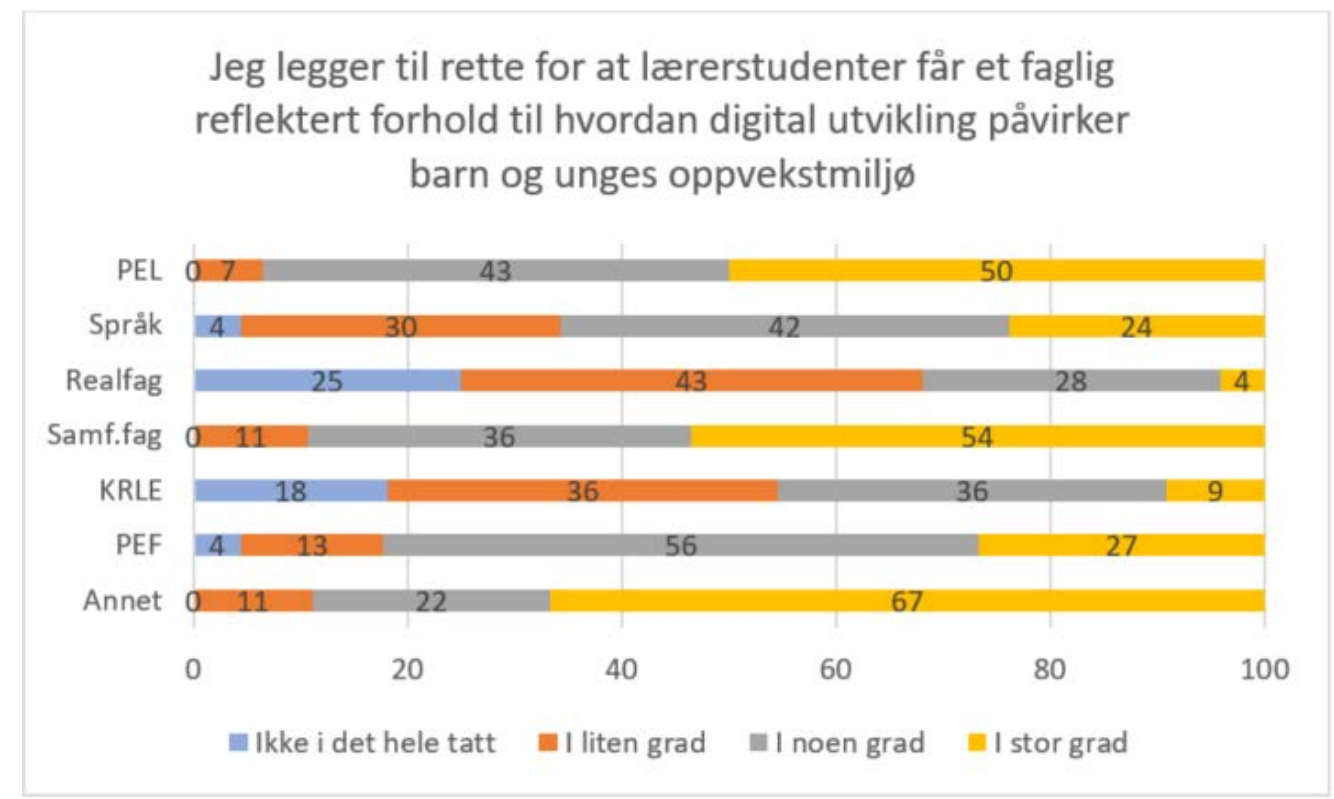

Figur 3. Digital utvikling og oppvekstmiljø

Av PEL-lærerne svarer $93 \%$ at de i noen eller i stor grad legger til rette for dette. Derimot svarer $68 \%$ av lærerne i realfag og $54 \%$ av lærerne i KRLE at de i liten grad eller ikke i det hele tatt legger til rette for det. Realfag skårer signifikant ( $<<0.001)$ lavere enn språk, samfunnsfag, PEF og «annet». PEL skårer signifikant $(p<0.05)$ høyere enn språk, realfag og KRLE. Samfunnsfag skårer signifikant $(p<0.05)$ høyere enn KRLE. 


\section{Etikk}

Figur 4 illustrerer forskjellene mellom de ulike faggruppenes arbeid med å avdekke, forebygge og håndtere digital mobbing, krenkelser og uønskede hendelser.

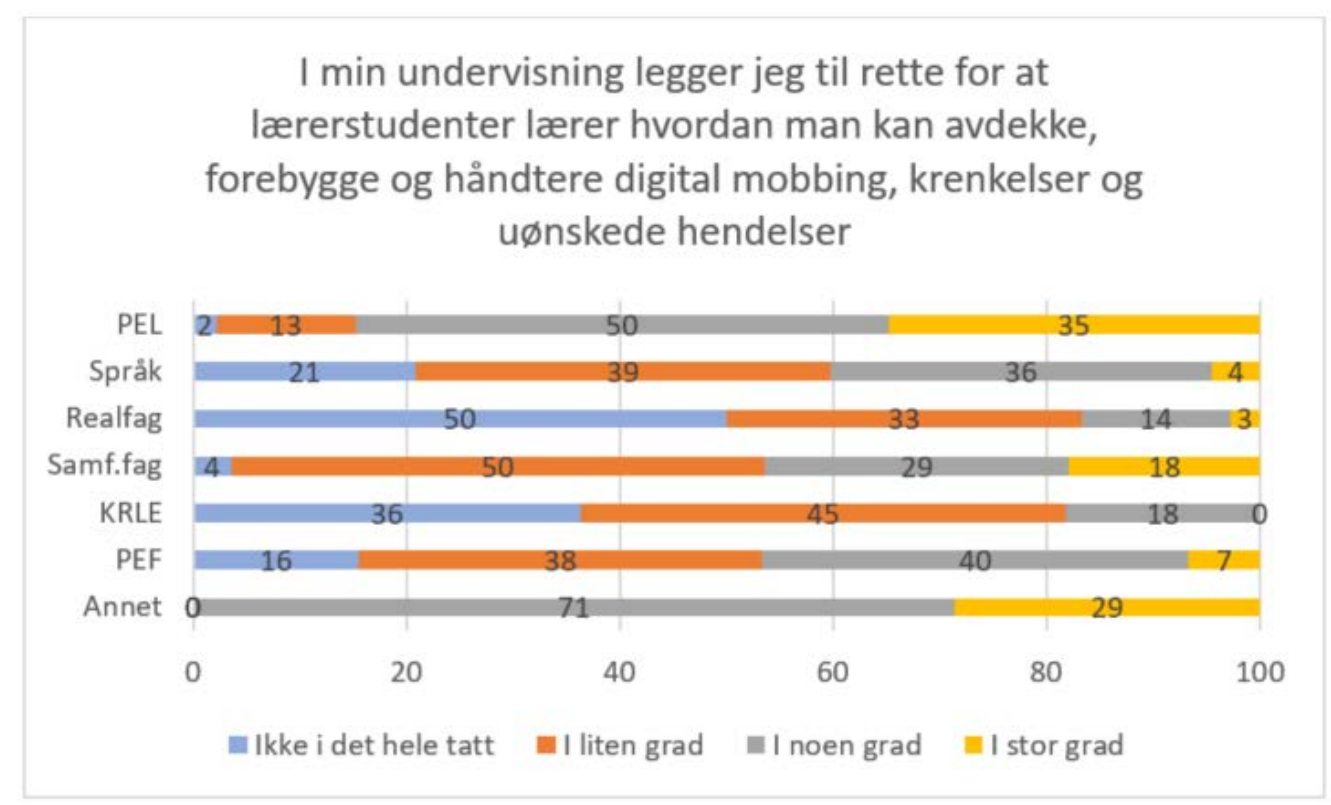

Figur 4. Digital mobbing, krenkelser og uønskede hendelser

Av KRLE-lærerne oppgir $81 \%$ at de i liten grad eller ikke i det hele tatt legger til rette for at studenter lærer å avdekke, forebygge og håndtere digital mobbing. $83 \%$ av realfagslærerne responderer at de ikke i det hele tatt eller i liten grad arbeider med dette. Lærerutdannere i PEL oppgir å jobbe mest med digital mobbing (85 \%), etterfulgt av PEF (47 \%) og samfunnsfag (47 \%). PEL skårer signifikant $(\mathrm{p}<0.01)$ høyere enn språkfag, realfag, KRLE og PEF.

\section{Pedagogikk, fagdidaktikk og ledelse av læringsprosesser}

Figur 5 viser i hvilken grad lærere fra ulike fag forbereder studentene når det gjelder å forebygge digital utenomfaglig aktivitet. For seks av de sju faggruppene er det kun en liten andel (3-8 \%) som rapporterer at de i stor grad jobber med dette temaet. Spennet for de som svarer i liten grad eller ikke i det hele tatt på dette utsagnet, strekker seg fra 50 \% i PEL til $92 \%$ i KRLE. PEL skårer her signifikant $(\mathrm{p}<0.05)$ høyere enn realfag. Realfag, KRLE og PEF skårer signifikant $(\mathrm{p}<0.05)$ lavere enn «annet». 


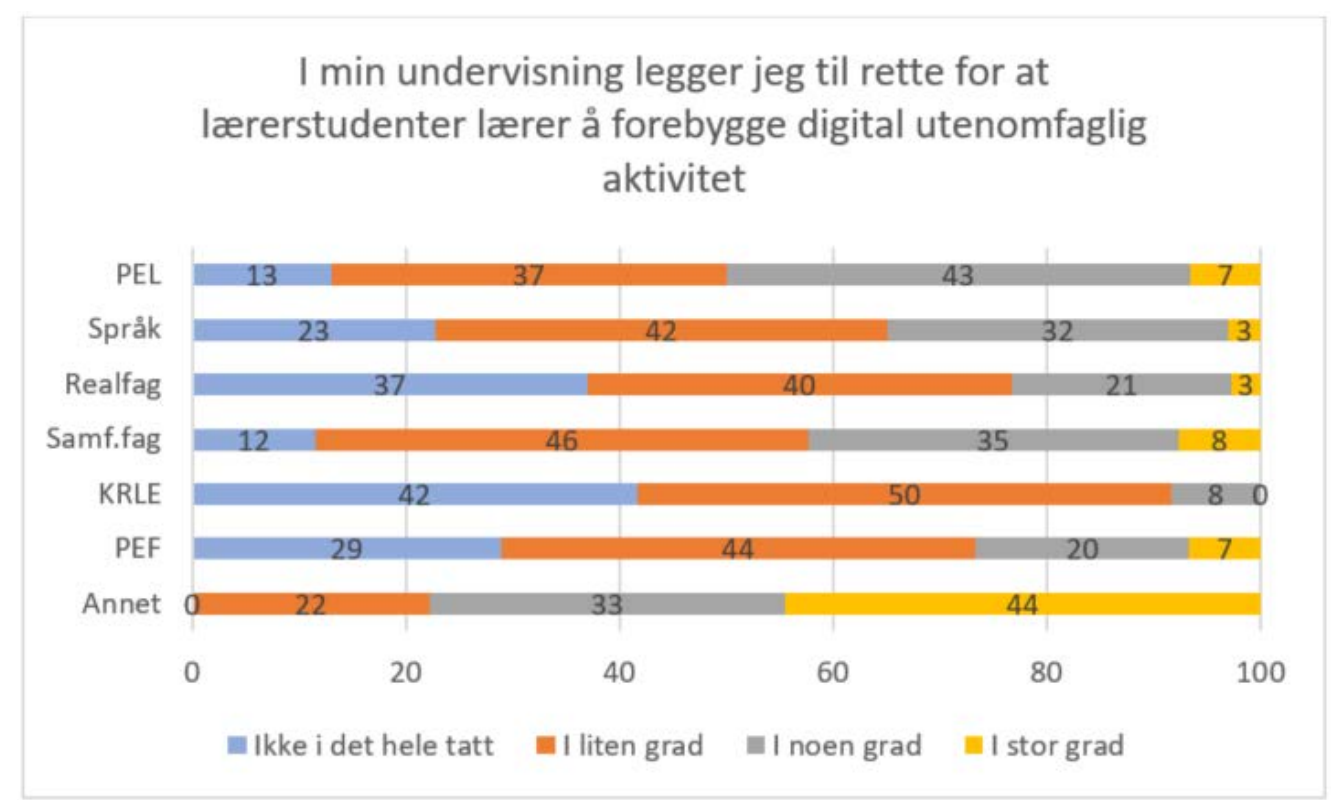

Figur 5. Utenomfaglig aktivitet

\section{Samhandling og kommunikasjon}

Figur 6 viser hvordan ulike faggrupper jobber med temaet delingskultur.

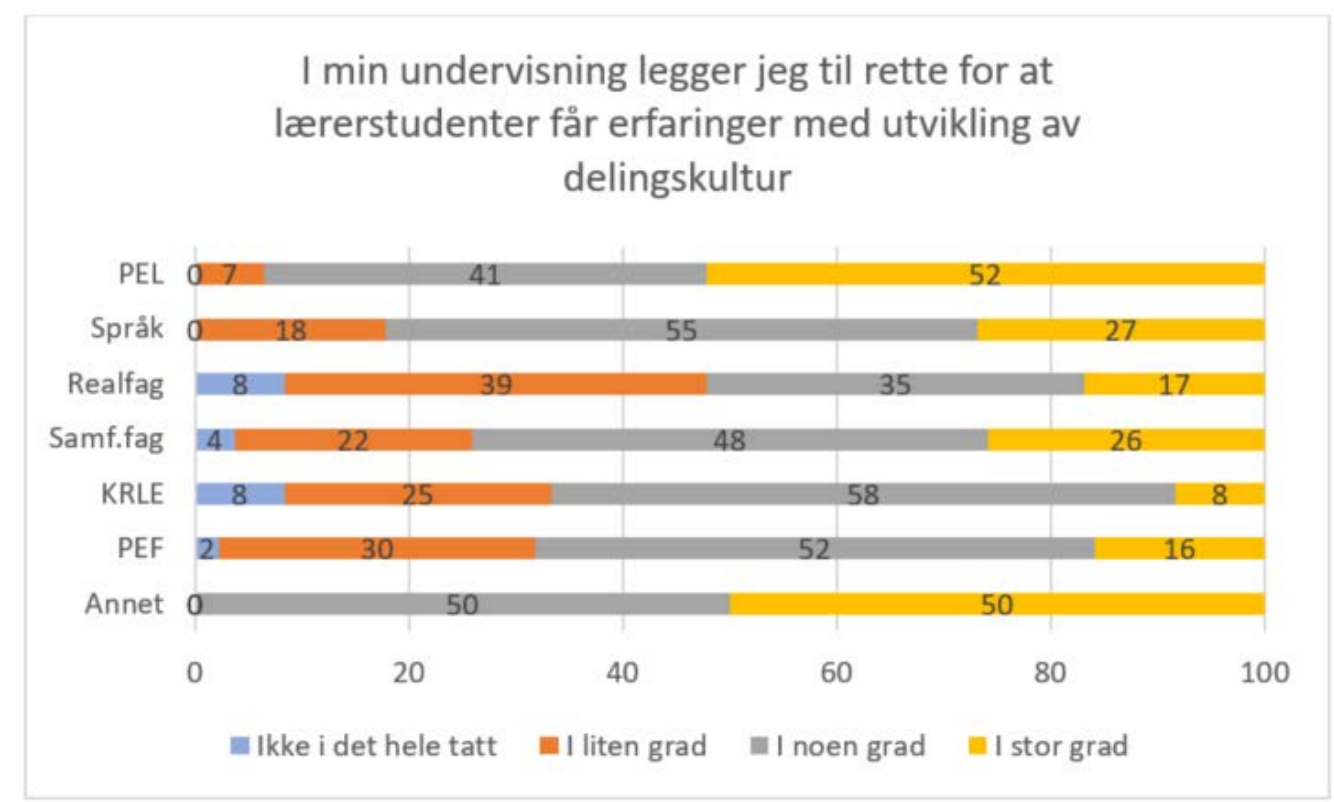

Figur 6. Delingskultur

Få lærerutdannere svarer at de ikke i det hele tatt gir studenter erfaringer med å utvikle en delingskultur. Samlet sett oppgir $47 \%$ av lærerutdannerne i faggruppen realfag, 33 \% i KRLE og 32 \% i PEF at de ikke i det hele tatt eller kun i liten grad legger til rette for dette. PEL skårer signifikant $(p<0.05)$ høyere enn realfag, KRLE og PEF. Språkfag skårer signifikant $(\mathrm{p}<0.05)$ høyere enn realfag. Realfag er signifikant $(\mathrm{p}<0.05)$ lavere enn «annet». 


\section{Oppsummering av funn}

I studiens første forskningsspørsmål spør vi om hvilken betydning fagtilknytning har for lcererutdannernes arbeid med PfDK. Vi påviser en tydelig sammenheng mellom faggruppetilhørighet og hvordan lærerutdannere arbeider med PfDK, men også at vurdering av nivå på egen teknologibruk i undervisningen kan ha betydning for arbeidet. Når det gjelder studiens andre forskningsspørsmål, hva karakteriserer arbeidet med implementering av PfDK i fagene, oppgir PEL-lærere og lærerutdannere i kategorien «annet» at de i større grad enn de andre jobber med PfDK-tematikk. Lærerutdannere fra samfunnsfag jobber mer enn gjennomsnittet med PfDK, de som tilhører språkfag og praktisk-estetiske fag ligger nært opptil gjennomsnittet, mens lærerutdannere fra KRLE og realfag oppgir å jobbe mindre med PfDK enn de andre faggruppene. Den forklarte variansen $\left(\mathrm{R}^{2}\right)$ indikerer at fagtilhørighet betyr mest for hvordan lærerutdannere jobber med PfDK-området Skolen i samfunnet, og minst for området Fag og grunnleggende ferdigheter. Sammenlignet med kontrollvariablene har fagforskjellene gjennomgående den høyeste partielle effektstørrelse $\left(\eta^{2}\right)$ for alle PfDK-områdene. Unntaket er variabelen "vurdering av nivå på egen teknologibruk" som har særlig stor betydning for hvordan lærerutdannerne oppgir å jobbe med områdene Fag og grunnleggende ferdigheter og Pedagogikk, fagdidaktikk og ledelse av læringsprosesser. I tillegg til at studien viser variasjoner mellom fag, finner vi også at noen PfDK-temaer i liten grad vies oppmerksomhet uavhengig av fag.

\section{Diskusjon}

Resultatene våre bekrefter tidligere funn (Gudmundsdottir \& Hatlevik, 2018; Gudmundsdottir et al., 2014; Krumsvik, 2016; Tømte et al., 2013) som viser at LU i Norge har et stykke å gå når det gjelder å legge til rette for studenters PfDKutvikling.

Til forskjell fra andre studier, svarer vår studie på hvordan lærerutdannere fra ulike faggrupper legger til rette for studenters PfDK-utvikling. Vi forventet forskjeller, men det var likevel uventet at noen sentrale PfDK-temaer i liten grad behandles i utdanningen, og at det er signifikante forskjeller i hvordan fagene jobber med PfDK, der noen fag skiller seg ut ved å rette PfDK lite oppmerksomhet. Selv om studiene ikke kan sammenlignes direkte, er det likevel interessant å merke seg at Voithofer et al. (2019) fant relativt små forskjeller mellom fag når det gjelder integrering av TPACK (Koehler \& Mishra, 2009) i amerikanske lærerutdanninger.

NIFUs første analyse tyder på at lærerutdannerne på tvers av fag har en rimelig omforent opplevelse av at digitalisering endrer arbeidsmåter og lærerrollen, men er mindre sikre på om fagenes innhold endres (Daus et al., 2019). Våre analyser 
tilfører kunnskap om i hvilken grad fagene inkluderer nye faglige PfDKproblemstillinger som vokser frem i en digital tid.

I tillegg til fagtilhørighet har lærerutdannernes vurdering av nivå på egen teknologibruk betydning for hvordan de jobber med PfDK. Tidligere studier (Uerz et al., 2018) har pekt på at lærerutdannere trenger både å kunne bruke digital teknologi, men også å kunne reflektere over hvordan den tas i bruk i fagene i LU. Studien vår kan tyde på at Tømte et al. (2013) sin anbefaling om å støtte lærerutdannere slik at de blir trygge og reflekterte brukere av digital teknologi i egen undervisning, fremdeles er aktuell.

\section{Profesjonsorientering virker utfordrende}

Studien viser at en del profesjonsnære PfDK-temaer som opptar skolen og samfunnet, i liten eller i variert grad blir tematisert i GLU. Som nevnt innledningsvis er for eksempel utenomfaglig aktivitet en sentral utfordring i teknologirike klasserom (Blikstad-Balas, 2013; Wølner et al., 2019). I lys av dette er det interessant å se at få lærerutdannere legger til rette for at lærerstudenter lærer å forebygge slik aktivitet. Vi vet også fra tidligere studier at digital teknologi kan brukes til å tilpasse opplæringen til elever på nye og bedre måter (Tømte et al., 2019; Wølner et al., 2019). Likevel er det bare en liten andel av lærerutdannerne fra de ulike faggruppene som svarer at de tilrettelegger for at studentene lærer om differensiering og tilpasset opplæring i teknologirike klasserom. Når det gjelder digital mobbing, ser det ut til å være en internasjonal utfordring at skoler, lærere og lærerutdannere trenger mer innsikt i hvordan de kan forebygge, avdekke og håndtere dette (Macaulay et al., 2018). Vår studie viser at lærerutdannere i realfag, språkfag og KRLE i liten grad tematiserer digital mobbing, mens lærerutdannere i PEL, samfunnsfag og PEF tematiser det i noen grad. Funnene viser at GLU har behov for å diskutere nærmere hvordan den skal forholde seg til at PfDK-temaer som opptar samfunn, skole og forskere på feltet, vies svak eller varierende oppmerksomhet i fag.

Store variasjoner i måten de profesjonsnære PfDK-temaene behandles på i fag, kan resultere i at studenter ikke møter de forbildene de trenger for å utvikle sin egen PfDK. En lærerutdanner står overfor komplekse kompetansekrav og skal fungere både som praktiker og forsker (Ulvik \& Smith, 2016, 2018). I PfDKarbeidet forventes de både å legge til rette for forskningsbasert kompetanseutvikling i fag og anvende kunnskap om et praksisfelt som i dag er preget av digitalisering. Både nasjonalt og internasjonalt argumenters det for at lærerutdannere bør være gode forbilder for hvordan digital teknologi brukes i undervisningen (Røkenes \& Krumsvik, 2016; Uerz et al., 2018). De komplekse forventningene som stilles til en lærerutdanner og den varierte rolleforståelsen lærerutdannere kan ha, kan forklare hvorfor de profesjonsnære PfDK-temaene ikke behandles systematisk i og på tvers av fagene. Svært mange studier fokuserer på hvordan lærerutdannerne bruker teknologi i sin egen undervisning, mens få retter oppmerksomhet mot fag og problemstillinger knyttet til å være en «second- 
order teacher» (Uerz et al., 2018). Våre funn tyder på at det er behov for mer kunnskap om hvordan lærerutdannere forholder seg til denne doble rollen og hvordan de kan støttes for å håndtere det komplekse kompetansekravet de står overfor.

\section{Forankring og institusjonalisering}

Når vi finner at ulike fag forholder seg ulikt til PfDK-temaer, gir det grunn til å diskutere i hvilken grad studie- og emneplaner operasjonaliserer hvordan PfDK skal arbeides med i fag. Vi vet fra før (Tømte et al., 2013) at arbeidet med digital kompetanse i liten grad har vært forankret i emneplaner og ledelse, og at PfDKopplæringen har vært fragmentert og overlatt til ildsjeler. Våre funn bekrefter NIFUs første analyse av surveyen (Daus et al., 2019) som konkluderer med at det er en utvikling i retning av mer institusjonalisert og systematisert PfDK-arbeid i GLU. Likevel kan både våre og NIFUs analyser tyde på at PfDK-arbeidet trenger tydeligere ledelse og klarere forankring i emneplaner.

GLU som modell kan gjøre det krevende å sikre at alle studenter utvikler PfDK. Studentene, særlig i GLU 5-10, har få fellesfag, men skal utvikle kunnskap om en rekke tverrfaglige temaer som PfDK. Når faglærerne jobber ulikt med PfDK-temaer, stilles institusjonene overfor et dilemma. Uten tydelig samordning og institusjonalisering, ved at PfDK-ansvar konkretiseres i fag eller ivaretas gjennom tverrfaglige strukturer (Rindal et al., 2015), blir studentenes PfDK tilfeldig og avhengig av deres studieportefølje. Foulger et al. (2017) påpeker at det er større mulighet for å lykkes med å utvikle studentenes digitale kompetanse dersom man integrerer arbeidet i fag, og at det bør være et mål å utvikle en lærerutdanning der problemstillinger knyttet til læring og teknologi adresseres samordnet og gjennomgående i hele studiet.

Selv om det er utfordrende å endre institusjonelle og historisk dypt forankrede praksiser (Engeström, 1987), vet vi at samarbeid fremmer forutsetningene for å lykkes (Hakkarainen, Palonen, Paavola \& Lehtinen, 2004). Enkelte lærerutdanningsinstitusjoner har erfart at tverrfaglig samarbeid om PfDK bidrar til å sikre helhet og sammenheng i utdanningen (Rindal et al., 2015), mens andre peker på at det er vanskelig å administrere (Maagerø, Prøitz, Rye \& Simonsen, 2019).

\section{Å operasjonalisere et rammeverk}

Utdanningsdirektoratet har utviklet PfDK-rammeverket blant annet for å gi lærerutdanninger retning for PfDK-arbeidet. Rammeverket er relativt nytt. Voithofer et al. (2019) finner i sin studie av hvordan rammeverket TPACK integreres i amerikansk lærerutdanning, at av de $62 \%$ som svarer at de ikke har integrert TPACK, er det $32 \%$ som ikke er kjent med rammeverket. Dette indikerer at det tar tid å gjøre et rammeverk kjent, og i tolkningen av våre funn må vi ta høyde for dette.

Resultatene våre tyder likevel på at rammeverket er lettest å operasjonalisere i PEL. Dataene gir ikke innsikt i årsaken, men tidligere forskning (f.eks. Aagaard, 
2015; Aase, 2009) indikerer at teknologiutløste problemstillinger utfordrer noen fag og fagtradisjoner mer enn andre. Kanskje målformuleringene i rammeverket i mindre grad utfordrer fagtradisjoner i PEL, sammenlignet med andre fag? PEL har tradisjon for å tematisere profesjonsfaglige og generiske pedagogiske problemstillinger som det er en del av i rammeverket, mens fagene har tradisjon for å fokusere mer på rene fag- og fagdidaktiske temaer.

Internasjonalt er det anbefalt å ta i bruk koherente teknologirammeverk i lærerutdanningsprogram (Nelson et al., 2019). En stor utfordring for operasjonalisering i fag er at overordnede modeller som PfDK-rammeverket, men også TPACK (Koehler \& Mishra, 2009) og DigCompEdu (Redecker, 2017), er svakt forankret i fag. En løs kobling til fag og fagtradisjoner kan gjøre det krevende å anvende dem i studieprogram som i vesentlig grad bygger på ulike fag og hvor det er lite tradisjon for tverrfaglig samarbeid.

Samlet sett tyder studien vår på at rammeverket gir retning for lærerutdannernes arbeid med PfDK, men at det er stort behov for å operasjonalisere PfDK ytterligere i studieprogram, i emneplaner og i de ulike fag. Rammeverket skal oppdateres «regelmessig i tråd med påvirkningen den digitale utviklingen har på lærerprofesjonen og utdanningssystemet generelt» (Kelentrić et al., 2017, s. 3). Aagaard og Lund (2020) etterspør fokus på epistemologiske konsekvenser av digitalisering i rammeverket. Resultatene våre viser hvordan fag forholder seg til PfDK-områder og kan anvendes i en revisjonsfase for å sikre at rammeverket kommuniserer tydelig med fagene. Uavhengig av revisjon anser vi likevel rammeverket som verdifullt fordi det utfordrer lærerutdannere til å diskutere hvordan utdanningen generelt og fagene spesielt kan gjøres mer dagsaktuelle og profesjonsrelevante.

\section{Implikasjoner}

Intensjonen med studien var å kartlegge hvordan lærerutdannere fra ulike fag forholder seg til PfDK, slik PfDK beskrives i rammeverket, og legge til rette for en diskusjon som grunnlag for kunnskapsbasert utvikling av GLU. I en skole og et samfunn preget av digitalisering trenger vi en lærerutdanning som ruster studentene godt for de muligheter og utfordringer de vil møte i yrket. Det varierende PfDK-arbeidet i fag gir grunn til å spørre om lærerutdannerne selv trenger et PfDK-løft. Videre viser vi at det er behov for å diskutere hvordan utdanningen forholder seg til PfDK-temaer som opptar samfunn, skole og forskere på feltet, men som synes å bli svakt ivaretatt i GLU.

At fagenes PfDK-ansvar ikke er adressert i rammeverket, er forståelig fordi rammeverket er skrevet for profesjon og ikke lærerutdanning primært. Men for en lærerutdanning med få fellesfag og svak tradisjon for tverrfaglig samarbeid, er det krevende å implementere et rammeverk som ikke er koblet til fag. Vi anbefaler derfor at studien tas $\mathrm{i}$ betraktning når rammeverket skal revideres og 
implementeres i LU. Hvordan GLU skal organiseres for å sikre både faglig dybde og helhetlig behandling av tverrfaglige, profesjonsnære temaer som PfDK, fortjener oppmerksomhet både lokalt på ledernivå, men også i nasjonale fora.

PfDK-rammeverket og KDs prosjektstøtte til digitalisering av GLU er nasjonale, strukturelle grep for å støtte utvikling av PfDK i lærerutdanningen. Vår studie gir et bilde av hvordan lærerutdannere i ulike fag jobbet med PfDK rett før Covid-19. Den vil derfor være et viktig referansepunkt for undersøkelser om hvilken rolle pandemien, en annen potensiell "game changer» (Avelino, Wittmayer, Kemp \& Haxeltine, 2017), vil spille for videre arbeid med og forståelse av PfDK.

\section{Begrensninger}

I fortolkning av funn fra denne studien bør man være oppmerksom på noen forhold som begrenser generaliserbarheten av resultatene. Alle respondentene jobber ved en av de fem institusjonene som i 2017 fikk midler fra KD til digitaliseringsprosjekter i GLU. De har dermed andre vilkår for å jobbe med PfDK enn landets øvrige lærerutdanningsinstitusjoner, og utvalget er ikke nødvendigvis representativt for institusjoner som ikke har fått midler. Videre kan selvseleksjon ha ført til overrepresentasjon av PfDK-interesserte lærerutdannere. Responsraten på noe under $50 \%$ medførte at antallet respondenter i hver faggruppe ble relativt lite. Derfor kunne vi også bare inkludere én kontrollvariabel av gangen i variansanalysen, men selv da var ikke alle statistiske forutsetninger for variansanalyser oppfylt for hver gruppe. Imidlertid peker Field (2013, s. 444-445) på at variansanalyser er ganske robuste mot avvik fra normalfordelingsforutsetningen; derfor gjennomførte vi analysen selv om denne forutsetningen ikke var innfridd i alle tilfeller. Brudd på forutsetninger om homogen varians er derimot mer alvorlig, fordi det gjør estimatene av standardfeil usikre. I tilfeller hvor det var heterogen varians, har analysen derfor blitt bootstrapped (Field, 2013, s. 520). Resultatene indikerte at variansanalysen var forsvarlig, siden gruppeforskjellene forble signifikante.

Da surveyen ble gjennomført, var PfDK-rammeverket nytt og derfor sannsynligvis ukjent for mange lærerutdannere. Vi anbefaler derfor en ny survey når rammeverket er blitt godt kjent og implementert i GLU. I den forbindelse bør også de lærerutdanningsinstitusjonene som ikke har fått prosjektmidler, inkluderes. Det vil gi innsikt i PfDK-utviklingen i GLU generelt og hvilken betydning nasjonale tiltak med særskilt finansiering kan ha for å fremme arbeidet med PfDK.

Surveyen bygger på PfDK-rammeverket og har ikke vært gjennomført tidligere. Både vi og Daus et al. (2019) har pekt på behov for å revidere batteriet hvis det skal gjenbrukes. Blant annet anbefaler vi at PfDK-området Endrings- og utviklingskompetanse kartlegges grundigere. Utviklingen på digitaliseringsfronten går fort og fører med seg at lærere på tvers av utdanningsnivå står overfor 
en felles utfordring: å utdanne for en delvis ukjent fremtid (Aagaard \& Lund, 2020). Det krever endrings- og utviklingskompetanse. I tillegg ser vi behov for andre typer studier som kan supplere og nyansere kunnskapen om hvordan det jobbes med PfDK i GLU.

\section{Om forfatterne}

Hjørdis Hjukse er seksjonssjef for USN eDU, enhet for Digitalisering og Utdanningskvalitet, og er knyttet til forskergruppen for læring, læringsdesign og digitale medier ved Fakultet for humaniora, idretts- og utdanningsvitenskap ved Universitet i Sørøst-Norge. Hennes forskningsinteresser omfatter utdanningskvalitet og læring i teknologirike læringsmiljø og utdanningsfaglig kompetanse i høyere utdanning.

Institusjonstilknytning: eDU, Universitetet i Sørøst-Norge, Postboks 235, 3603

Kongsberg.

E-post: hjordis.hjukse@usn.no

Toril Aagaard er førsteamanuensis i pedagogikk ved Institutt for pedagogikk ved Universitet i Sørøst-Norge. Hun leder prosjektet Læring og Undervisning i Digitale Omgivelser (LUDO). Hennes forskningsinteresser er knyttet til utdanningskvalitet og utvikling i teknologirike læringsmiljø. Hvordan forholder lærere seg til spenninger som oppstår når teknologi forårsaker at tradisjonelle didaktiske praksiser ikke fungerer som før?

Institusjonstilknytning: Fakultet for humaniora, idretts- og utdanningsvitenskap, Universitetet i Sørøst-Norge, Postboks 235, 3603 Kongsberg.

E-post: toril.aagaard@usn.no

Agnete Andersen Bueie er førsteamanuensis i norsk ved Institutt for språk og litteratur ved Universitet i Sørøst-Norge. Hennes forskningsinteresser er innenfor skriveforskning, mer spesifikt skriving og vurdering. Hun er også opptatt av digitalisering og norskfaget.

Institusjonstilknytning: Fakultet for humaniora, idretts- og utdanningsvitenskap, Universitetet i Sørøst-Norge, Postboks 235, 3603 Kongsberg.

E-post: agnete.bueie@usn.no

Thomas Moser er professor i utdanningsvitenskap ved Institutt for pedagogikk ved Universitet i Sørøst-Norge. Hans forskningsinteresser er barnehageforskning, kropp og læring, og undervisning og læring i digitale miljøer.

Institusjonstilknytning: Fakultet for humaniora, idretts- og utdanningsvitenskap, Universitetet i Sørøst-Norge, Postboks 235, 3603 Kongsberg.

E-post: Thomas.Moser@usn.no 
Karl Solbu Vika har en mastergrad i Comparative Politics fra London School of Economics and Political Science og er forskningsassistent ved Institutt for pedagogikk ved Universitet i Sørøst-Norge.

Institusjonstilknytning: Institutt for pedagogikk, Universitetet i Sørøst-Norge, Postboks 235, 3603 Kongsberg.

E-post: ksvika@live.no

\section{Referanser}

Arstorp, A.-T. (2015). Teknologi på lcereruddannelsen - en forestillet eller en realiseret praksis? Doktoravhandling. Aarhus Universitet. Hentet fra https://pure.au.dk/portal/files/87307660/AfhandlingArstorp.pdf

Avelino, F., Wittmayer, J. M., Kemp, R. \& Haxeltine, A. (2017). Game-changers and transformative social innovation. Ecology and Society, 22(4), Guest Editorial. https://www.learntechlib.org/p/29544/

Blikstad-Balas, M. (2013). Redefining School Literacy. Prominent literacy practices across subjects in upper secondary school. Doktoravhandling. Universitet i Oslo. Hentet fra https://www.duo.uio.no/bitstream/handle/10852/38160/1/dravhandling-blikstad-balas.pdf

Daus, S., Aamodt, P. O. \& Tømte, C. (2019). Profesjonsfaglig digital kompetanse i lcererutdanningene. Undersøkelse av tilstand, holdninger og ferdigheter ved fem grunnskolelcrerutdanninger. NIFU. Hentet fra http://hdl.handle.net/11250/2602702

Engeström, Y. (1987). Learning by expanding: an activity-theoretical approach to developmental research. Helsinki: Orienta-Konsultit Oy.

Field, A. (2013). Discovering statistics using IBM SPSS statistics: and sex and drugs and rock ' $n$ ' roll (4. utg.). Los Angeles: SAGE.

Fjørtoft, S. O., Thun, S. \& Buvik, M. P. (2019). Monitor 2019: En deskriptiv kartlegging av digital tilstand i norske skoler og barnehager. SINTEF.

Foulger, T. S., Graziano, K. J., Schmidt-Crawford, D. \& Slykhuis, D. A. (2017). Teacher educator technology competencies. Journal of Technology and Teacher Education, 25(4), 413-448. Hentet fra https://www.learntechlib.org/p/181966/

Furberg, A. L. \& Lund, A. (2016). En profesjonsfaglig digitalt kompetent lærer? Muligheter og utfordringer i teknologirike læringsomgivelser. I R. J. Krumsvik (red.), Digital læering i skole og lærerutdanning (s. 26-48). Oslo Universitetsforlaget.

Gudmundsdottir, G. B. \& Hatlevik, O. E. (2018). Newly qualified teachers’ professional digital competence: implications for teacher education. European Journal of Teacher Education, 41(2), 214-231. https://doi.org/10.1080/02619768.2017.1416085

Gudmundsdottir, G. B., Loftsgarden, M. \& Ottestad, G. (2014). Nyutdanna lærarar: Profesjonsfagleg digital kompetanse og røynsler med IKT i lærarutdanninga. Tromsø: Senter for IKT i utdanninga. Hentet fra https://www.udir.no/contentassets/fb484acf74dc4eb3bea0f16bf9995641/nulrapport_nynorsk.pdf

Hakkarainen, K., Palonen, T., Paavola, S. \& Lehtinen, E. (2004). Communities of networked expertise: Professional and educational perspectives. Amsterdam: Elsevier Scientific Publ.

KD (2009). Læreren: Rollen og Utdanningen. St.meld. nr. 11 (2008-2009). Oslo: Kunnskapsdepartementet. Hentet fra https://www.regjeringen.no/no/dokumenter/stmeldnr-11-2008-2009-/id544920/?ch=1 
Kelentrić, M., Helland, K. \& Arstorp, A.-T. (2017). Rammeverk for læererens profesjonsfaglige digitale kompetanse. Oslo: Senter for IKT i utdanningen. Hentet fra https://www.udir.no/kvalitet-og-kompetanse/profesjonsfaglig-digitalkompetanse/rammeverk-larerens-profesjonsfaglige-digitale-komp/

Koehler, M. J. \& Mishra, P. (2009). What Is Technological Pedagogical Content Knowledge (TPACK)? Contemporary Issues in Technology and Teacher Education (CITE Journal), 9(1), 60-70. Hentet fra https://www.learntechlib.org/p/29544/

Kongsgården, P. (2018). Vurderingspraksiser i teknologirike læeringsmiljøer: En undersøkelse av læreres vurderingspraksiser i teknologirike læringsmiljøer og implikasjoner på elevenes medvirkning i egen læringsprosess. Doktoravhandling. Universitetet i Bergen. Hentet fra http://bora.uib.no/bitstream/handle/1956/19273/Dr.thesis_2019_Petter\%20Kongsg\%c3\%a 5rden.pdf?sequence $=3 \&$ isAllowed $=\mathrm{y}$

Krumsvik, R. J. (red.) (2016). Digital læering i skole og lærerutdanning (2. utg.). Oslo: Universitetsforlaget.

Lund, A., Furberg, A. L., Bakken, J. \& Engelien, K. L. (2015). Hva er profesjonsfaglig digital kompetanse (PfDK) i lærerutdanningen? I U. E. Rindal, A. Lund \& R. E. Jakhelln (red.), Veier til fremragende lcererutdanning (s. 117-126). Oslo: Universitetsforlaget.

Macaulay, P. J. R., Betts, L. R., Stiller, J. \& Kellezi, B. (2018). Perceptions and responses towards cyberbullying: A systematic review of teachers in the education system. Aggression and Violent Behavior, 43, 1-12. https://doi.org/10.1016/j.avb.2018.08.004

Mulder, M., Gulikers, J., Biemans, H. \& Wesselink, R. (2009). The new competence concept in higher education: error or enrichment? Journal of European Industrial Training, 33(8/9), 755-770. https://doi.org/10.1108/03090590910993616

Maagerø, E., Prøitz, T. S., Rye, E. \& Simonsen, B. (2019). Femårig masterutdanning for grunnskolelærere - ny og utfordrende. Skriftserien fra Universitetet i Sørøst-Norge nr. 30. Hentet fra https://openarchive.usn.no/usnxmlui/bitstream/handle/11250/2618233/2019_30_Maager\%c3\%b8.pdf?sequence=1\&isAl lowed $=\mathrm{y}$

Nelson, M. J., Voithofer, R. \& Cheng, S.-L. (2019). Mediating factors that influence the technology integration practices of teacher educators. Computers \& Education, 128, 330 344. https://doi.org/10.1016/j.compedu.2018.09.023

Redecker, C. (2017). European Framework for the Digital Competence of Educators: DigCompEdu. EUR 28775 EN. Luxembourg: Publications Office of the European Union. Hentet 28.01.20 fra https://ec.europa.eu/jrc/en/digcompedu

Rindal, U., Lund, A. \& Jakhelln, R. (red.) (2015). Veier til fremragende læererutdanning. Oslo: Universitetsforlaget.

Røkenes, F. M. \& Krumsvik, R. J. (2016). Prepared to teach ESL with ICT? A study of digital competence in Norwegian teacher education. Computers \& Education, 97, 1-20. https://doi.org/10.1016/j.compedu.2016.02.014

Rønningsbakk, L., Jakhelln, R. \& Vedeler, G. W. (2015). Digital kompetanse i lærerutdanningen - fra ildsjelkultur til integrasjon. I U. Rindal, A. Lund \& R. Jakhelln (red.), Veier til fremragende læererutdanning (s. 127-134). Oslo: Universitetsforlaget.

Tondeur, J., van Braak, J., Siddiq, F. \& Scherer, R. (2016). Time for a new approach to prepare future teachers for educational technology use: Its meaning and measurement. Computers \& Education, 94, 134-150. https://doi.org/10.1016/j.compedu.2015.11.009

Tømte, C., Kårstein, A. \& Olsen, D. S. (2013). IKT i læererutdanningen: På vei mot profesjonsfaglig digital kompetanse? NIFU. Hentet fra https://nifu.brage.unit.no/nifuxmlui/handle/11250/280429 
Tømte, C., Wollscheid, S., Bugge, M. \& Vennerød-Diesen, F. F. (2019). Digital lcering i askerskolen. Sluttrapport fra følgeforskning. NIFU. Hentet fra http://hdl.handle.net/11250/2631639

Uerz, D., Volman, M. \& Kral, M. (2018). Teacher educators' competences in fostering student teachers' proficiency in teaching and learning with technology: An overview of relevant research literature. Teaching and Teacher Education, 70, 12-23. https://doi.org/10.1016/j.tate.2017.11.005

Ulvik, M. \& Smith, K. (2016). Å undervise om å undervise - Lærerutdanneres kompetanse sett fra deres eget og fra lærerstudenters perspektiv. Uniped, 39(1), 61-77. https://doi.org/10.18261/issn.1893-8981-2016-01-06

Ulvik, M. \& Smith, K. (2018). Lærerutdanneres profesjonelle utvikling. Uniped, 41(04), 425440. https://doi.org/10.18261/issn.1893-8981-2018-04-05

Utdanningsdirektoratet (2018). Digitalisering i lærerutdanningene. Hentet 16.12.2019 fra https://www.udir.no/kvalitet-og-kompetanse/profesjonsfaglig-digitalkompetanse/digitalisering-i-larerutdanningene/

Voithofer, R., Nelson, M. J., Han, G. \& Caines, A. (2019). Factors that influence TPACK adoption by teacher educators in the US. Educational Technology Research and Development, 67(6), 1427-1453. https://doi.org/10.1007/s11423-019-09652-9

Voogt, J., Fisser, P., Pareja Roblin, N., Tondeur, J. \& Van Braak, J. (2013). Technological pedagogical content knowledge - a review of the literature. Journal of Computer Assisted Learning, 29(2), 109-121. https://doi.org/10.1111/j.1365-2729.2012.00487.x

Wølner, T. A., Egeberg, G., Moser, T., Bjørnsrud, H. \& Aagaard, T. (2019). Implementering av 1:1 iPad i Kongsberg, Larvik og Notodden kommune - første resultat fra ståstedsanalysen. Skriftserien fra Universitetet i Sørøst-Norge nr. 27. Hentet fra https://openarchive.usn.no/usn-xmlui/handle/11250/2599494

Aagaard, T. (2015). Når teknologi møter fagtradisjoner i norsk og mediefag på videregående skole. Acta Didactica Norge, 9(1), Art. 2. https://doi.org/10.5617/adno.1298

Aagaard, T. \& Lund, A. (2020). Digital Agency in Higher Education: Transforming Teaching and Learning. London: Routledge.

Aase, L. (2009). 30 år med norskdidaktikk. Innlegg presentert i Trondheim 10.03.2019. Hentet 05.06. 2020 fra https://docplayer.me/14767403-30-ar-med-norskdidaktikktrondheim-10-mars-2009-laila-aase.html 